Forthcoming in Religion, State and Society

\title{
Co-opting religion: how ruling populists in Turkey and Macedonia sacralise the majority
}

\author{
Bilge Yabanci* and Dane Taleski** \\ bilge.yabanci@su.se \\ danetaleski@yahoo.com
}

*Stockholm University Institute for Turkish Studies, Stockholm, Sweden

Bio note: Bilge Yabanci is a postdoctoral researcher at Stockholm University Institute for Turkish Studies (SUITS). Her current research interests include populism and ruling populist parties, the relationship between authoritarian consolidation and civil society, and democratic reversal in Turkey. She recently published two peer-reviewed articles: on Turkey's civil society and authoritarian consolidation in the Journal of Southeast European and Black Sea Studies and on left-wing populism within the context of Kosovo's contested statehood in Contemporary Southeastern Europe.

** South East European University, Skopje/Tetovo, Macedonia

Bio Note: Dane Taleski is a researcher working on the transformation of war-time networks into minority political parties in Croatia and Macedonia, and its implications for minority party competition, peacebuilding and post-conflict democratisation. In 2016, he published an article on political party regulation and party system formation in Macedonia's democratisation and on the maintenance of a hybrid regime in Macedonia in a special issue on 'Illiberal and Authoritarian Trends in Eastern Europe' in Religion and Society in East and West (RSEW).

Acknowledgements: This study was initiated as a collaborative work by the authors during their 2015-16 visiting fellowship at the Centre for Southeast European Studies (CSEES), University of Graz, Austria. The authors would like to thank CSEES for the collaborative and intellectually stimulating environment it offered, which made this article possible. We would also like to extend our thanks to the two anonymous reviewers for their helpful comments that allowed us to enrich the study. 


\begin{abstract}
Despite the remarkable scholarly attention to populism and populist parties, the relation between populism and religion remains understudied. Using evidence from two long-term ruling populist parties - Turkey's AKP and Macedonia's VMRO-DPMNE - this study focuses on how and why religion can be an instrument for populist politics at three levels: (i) discursive, (ii) public policy, and (iii) institutionalised alliances with religious authorities. The study highlights that religion comes into play at these three levels once populists attain comfortable electoral margins but encounter mounting political and economic challenges that can potentially weaken their grip on power. Ruling populists co-opt and monopolise the majority religion in the name of 'the people's will' as they increasingly undermine democratic legitimacy but they need to justify their systematic crackdown on dissent, the system of checks and balances, the rule of law and minorities. The empirical findings of the study also demonstrate the dual function of religion for populists: its catch-all potential to create cross-class and cross-ethnicity popular support and its instrumentality to discredit dissent as 'religiously unfit' while constructing an antagonism of 'the people' versus 'the elites'.
\end{abstract}

Keywords: religion, populism, Turkey, Macedonia, AKP, VMRO-DPMNE, democratic decline, authoritarianism 


\section{Introduction}

Any relation between religion and populism does not bode well at first sight. The universal and divine claims of religion seemingly contradict populism's mundane obsession with popular sovereignty and 'the people'. Populism places people's sovereignty above everything else promising to reassert the will of 'the virtuous people' - the ultimate source of legitimacy against 'the corrupt elites' and 'the enemies of the people'. Yet, moralism, inherent in the populist exaltation of the people's will, brings it close to the language of religion.

This study examines the relationship between religion and populism by comparing two cases of long-term ruling populist parties: Turkey's Justice and Development Party (AKP) and Macedonia's Internal Macedonian Revolutionary Organisation-Democratic Party for Macedonian National Unity (VMRO-DPMNE). Despite remarkable scholarly attention to the conceptual definition(s) and classification of populism(s) in the literature, the relations between religion and populism remain under researched (see Mudde 2007). Studies on the topic remain mostly limited to the European radical right-wing populism's rejection of Islam and the Muslim 'other' (e.g. Marzouki et al. 2016). These studies do not offer a systematic comparison of populist parties within the context of different faiths, nor do they examine whether or not a specific religion makes any difference on populism's or populist actors' self-positioning vis-à-vis religion. Given its strong nativism, radical right-wing populism is different from populism per se (Mudde 2007; Müller 2016; Taggart 2000). Rapid and irregular immigration, xenophobia and Islamophobia in the post-9/11 period have shaped the radical-right variant of populism in Europe, especially its relationship to religion and 'the religious other'. The anti-immigrant and anti-Islam approach of radical right-wing populism is a result of the contextual articulation of populism in 'the West'.

By comparing the role of religion in the AKP's and VMRO-DPMNE's populisms, this study aims to unearth broader relations between religion and populism that go beyond Islamophobia and scapegoating Muslim minorities. We focus on two 'non-Western' cases of populism and compare a predominantly Muslim country with a predominantly Christian Orthodox country. The study asks how populists reconcile the contradictory grounds of universalistic claims of religion and the specific appeal to the people, as well as how and why two populist parties in Turkey and Macedonia have utilised religion by incorporating religious appeals and symbols in their discourses, policies and electoral mobilisation strategies.

The extant literature also falls short of investigating whether being in power for an extended period alters populists' relations to religion and religious institutions. This study seeks to answer how the populist utilisation of religion has evolved at three levels: discursive, public policy, and alliances with main religious institutions. Religion can be a potent instrument of populist appeals to achieve political goals, to pursue controversial public policies, and to expand the elite coalition behind populists through the support of the main religious actors in the country, and thus to contribute to the survival of populist parties in power.

Our study also offers novel insights into the relationship between religion, majoritarianism and democracy. First, religious tenets can be used as a tool for populist authoritarian goals, strictly depending on the political actors and their ideologies. Populists in power tailor and instrumentalise the majority religion only once they achieve comfortable electoral majorities. Perceiving themselves as the embodiment of the people's will, they embark on majoritarian and increasingly authoritarian practices, crushing pluralism. When challenges to their governance rise in the form of political and civic dissent, ruling populist parties resort to religion 
when they need an alternative source of legitimation other than democratic legitimacy to justify their crackdown on dissent, systems of checks and balances, the rule of law, and minority rights

Our analysis shows that the dual function of religion for populists in power masks growing authoritarianism and the undemocratic nature of the populists' exclusive claim to representing 'the people': (i) its catch-all potential to create cross-class and cross-ethnicity coalitions in crafting 'the homogenous people' and (ii) its instrumentality in creating, tailoring and stabilising (meta-)cleavages in line with the populist 'us' versus 'others' dichotomy.

Second, by comparing the political instrumentalisation of two different religions, our study falsifies the overestimated differences between Islam and Christianity regarding their interaction with politics and democracy. While the politicisation of Islam has been in the spotlight since the post-9/11 political atmosphere, our study shows that populists tailor and adopt religious appeals for political power similarly, regardless of the content of the specific religious doctrine.

We first introduce our analytical framework and hypotheses regarding the relationship between populism and religion. Then we turn to our case studies to investigate how the AKP and the VMRO-DPMNE have incorporated religion into their populist political mobilisation and how their relations with the dominant religions and religious authorities have evolved. The analysis is based on data from party documents, legislation and policy documents, speeches by party elites and religious authorities in online media, and secondary sources. We combine cross-case in-depth analysis with a longitudinal study of two ruling populist parties delimited by their three consecutive terms in office.

\section{Populism: a brief definition}

Although populism has been subject to conceptual stretching and misuse in the media and political discourse, scholarly literature concisely defines the core aspects of populism as: (i) the dichotomy between 'us' ('the people') and 'the corrupted and self-interested elites'; (ii) the moral valorisation of 'the people' and the people's sovereignty; and (iii) the exclusive claim to the representation of 'the people' (Albertazzi and McDonnell 2008; Müller 2016; Mudde and Kaltwasser 2017).

Accordingly, populism claims that there is an endless antagonism between the people and the elites who are allegedly alienated from the people's culture and values. When referring to 'the people', populists imagine a uniform body 'untainted' by class, ethnicity or religious divisions, promoting instead an 'organic view as an ethnically and culturally homogenous totality' (Filc 2009, 12). As Mudde notes (2017), 'populists believe that all people share the same interests and values' and politics should be an unconditional expression of 'the will of the people'. As a result, populist politics always demonise certain groups that reject or do not 'fit' the category of the pure people, such as minorities, immigrants and dissidents.

The dark side of populism emerges when electoral results become "the only game in town' to determine the popular will. Populists 'pretend that no action of a populist government can be questioned, because "the people" have willed it so' (Müller 2015, 86). More particularly, ruling populists tend to 'confuse the government with the state' and perceive 'the exercise of political power as a possession rather than as occupancy' (Arditi 2007, 83). While claiming to be the only genuine representative of 'the homogenous people', populists are against pluralistic 
interest and group representation. They seek to incapacitate democracy's procedural qualities by attacking the principles and institutions of liberal democracy, such as the system of checks and balances, minority rights, gender quotas and other constitutional guarantees as 'elite fashions' (Yabanci 2016b).

\section{Populism and religion}

There is a limited discussion in the literature on the links between populism and religion. A few studies use the notion of 'religious populism' inconsistently to denote a form of political Islam (Hadiz 2014; Jati 2013), 'the politicisation' of the church's religious discourse (Stavrakakis 2002), or reactionary and radical religious movements (Yates 2007). The most systematic study by Marzouki et al. (2016) is mostly confined to western right-wing populist parties and focused on how populist 'nativism' marginalises 'the Muslim' from 'the pure people' (Mudde 2007).

We argue that the relationship between religion and populism should be first considered as an aspect of the broader and complex interactions between religion and politics, shaped by the opposed currents of secularisation and religious revivalism in modern states (Stark 1999; Berger 1999; Casanova 2007). While these complex processes are not the scope of this study, their interactions can be summarised as either 'the politicisation of religion' by religious movements/authorities that intervene into the political arena, or 'the religionisation of politics' by politicians for ideological or tactical reasons.

With regards to the particular relation between populism and religion, 'the politicisation of religion' pertains to religious upsurges taking a populist character when such movements initiate protest and resistance against secular elites 'over and beyond their purely religious motives' (Berger 1999, 11). The 'religionisation of politics', utilises religion to construct a moralistic and monist conception of politics as a mobilisation strategy. Through the religionisation of politics, 'the religiously inspired political ideology [is] made ready for the electoral battle to attract voters' (Kalyvas and Kersbergen 2010, 189).

Our focus here is the second type of relationship between populism and religion (summarised in Figure 1), where religion can be one of many instruments in constructing the fundamental antagonism between 'the people' and others, and in asserting the unity of the people. We are concerned with how and why religion is used because of its role in decoding and reconfiguring the dichotomy of 'the people' against 'the rest' promoted by populists in power and in justifying the refusal to acknowledge and protect the rights and demands of 'non-people'. In short, as Mudde and Kaltwasser note (2012, 1-2), 'we are interested here, first and foremost, in what the populist part of political actors contributes to the political agenda', not the religious part.

\section{[Insert Figure 1]}

We posit that religion first serves to 'siphon political grievances' by helping construct 'the fantasy of the people as one', free from divisions under a common religion (Lefort 1988, 20). The religious framing of anti-establishment sentiments against 'self-interested' elites carries the potential of maintaining popular support for populists in power (Hadiz 2014, 4). Through religion's catch-all potential, populists can achieve a specific form of 'social mobilisation based on asymmetrical multi-class coalitions' (Oxhorn 1998, 223). The populist use of religion bears close resemblance to majority nationalism which considers religion and the church as 
critical elements of constructing national myths and identity in several countries (Loizides 2009; Fokas 2006).

Second, religion also serves to create or 'stabilise social and cultural cleavages' (Kalyvas and Kersbergen 2010, 189) or to rearticulate them for the survival of populists. In this case, religion is utilised as a culture or identity marker to define in- and out-groups. Those groups that do not succumb to or fit into the populists' imagery of homogenous people are identified as outsiders and excluded from 'the people'.

Finally, we categorically distinguish between: (i) discursive (ii) public policy-making, and (iii) institutionalised alliances with religious institutions as the specific mechanisms through which religion comes into play in populist politics. The discursive use of religion refers to the assertion of 'the fantasy of unity without fissures' under a common religion (Arditi 2007, 83). Based on religious appeals, populists also revalidate and define 'the others' by 'extracting "the people" out of people' (Lefort 1988, 88). Discourse also produces social meaning and practice, and sets the agenda for public policy-making. The discursive use of religion makes religious values, norms and requirements socially salient by refashioning them as the values of the 'ordinary' and 'maltreated people' for the electorate.

When populists are in a ruling position, religion is also used to promote or justify majoritarian public policies by framing them through a reference to the majority religion. As populists have an exclusive claim to the representation of 'the people', religious appeals can easily marginalise the criticisms of the opposition and alternative policy suggestions by morally and religiously discrediting dissent.

Finally, at the institutional level, populists empower religious institutions and actors through alliances. Populists in power particularly need to convince their supporters that the threat from the establishment is continuously impending by ruling through multiple periods of crisis (Yabanci 2016c). In maintaining their power, religious authorities become useful allies to convey their message to the masses or to legitimate controversial and undemocratic practices and help them preserve broad electoral coalitions. However, populists can establish and sustain alliances with religious institutions as long as they can 'impose their vision of religion' on the religious authorities or co-opt them (Roy 2016, 190).

\section{Populist ruling parties and emerging authoritarianism in Turkey and Macedonia}

Seawright and Gerring $(2008,296)$ suggest that the choice of cases in research design should be guided by 'a useful variation on the dimensions of theoretical interest'. This study focuses on populist parties in power since they go beyond the discursive level and thus are able to instrumentalise religion in crafting policies and institutional alliances. As Table 1 suggests, among the major ruling populist parties in Europe, the cross-case characteristics of Turkey and Macedonia offer the most fertile venue to examine how populists in power co-opt religion.

\section{[Insert Table 1]}

Despite their differences regarding political history and experience with electoral democracy, Turkey and Macedonia cluster around similar issues defining their current socio-political landscapes that provide a prism through which to focus on how populists adopt and utilise religion over and beyond the particular religious doctrine. 
First, the AKP and the VMRO-DPMNE are the longest ruling populist parties in the region with comparable political ideologies besides populism. Both parties initially received an extensive domestic and international welcome based on their pro-EU agendas, institutional reforms and neoliberal economic policies in their early years of incumbency. Both parties have never defined themselves as religious parties. In early 2000s, the AKP distanced itself from its predecessor's Islamist ideology and claimed an ideological position beyond the right-left cleavage. The party's self-coined ideology of 'conservative democracy' embraced neo-liberal economic policy and a populist appeal from the very beginning, which was crystallised in its attack against the secular republican establishment in the name of 'the pious silent majority' (Yabanci 2016a). The VMRO-DPMNE emerged initially as a staunchly nationalist party in 1990. After a leadership change in 2004, its new leader Nikola Gruevski replaced the VMRODPMNE's nationalist ideology with a conservative and neo-liberal outlook, promising EU membership, policy reform and economic growth. Contrary to the AKP, the VMRO-DPMNE did not initially have a populist agenda against the establishment. It adopted the populist antielitism after the 2008 electoral victory.

During their incumbency over a decade, the AKP and the VMRO-DPMNE have each consolidated unprecedented electoral support (summarised in Figure 2) through populist appeals; they have gradually expanded their control over institutions, the judiciary and the media (Günay and Dzihic 2016). They have also attacked dissenting groups and the parliamentary opposition. Despite the prospect of EU membership, both countries have joined the current trend of 'democratic backsliding' and hybrid regimes under the rule of democratically elected governments (Diamond 2015).

\section{[Insert Figure 2]}

Second, there are similarities in terms of the history of state-religion relations and the presence of an 'ethnic and religious other'. Religion has been historically a part of the official nationbuilding process and a marker of national identity in Turkey and Macedonia. Both countries have problematic relations with their ethnic and religious minorities (Kurds and Alevis in Turkey, and Albanians in Macedonia). Recently, both have witnessed a revival of conservatism, mostly expressed through the increased public role of the two dominant religions, Sunni Islam and Orthodox Christianity, after the long-term state oppression of religion and religiosity under the secular military tutelage in Turkey and communism in Macedonia (Markovik et al. 2013; Çarkoğlu and Kalaycioglu 2009).

Finally, the dominance of two different faiths - Islam and Orthodox Christianity - also allows a longitudinal analysis of the relations between populism and religion, particularly how and why religion has progressively become an instrument for these populist parties during their incumbency.

\section{The Justice and Development Party (AKP) in Turkey}

\section{The first term (2002-2007)}

During its first term in office, the AKP emphasised democracy, conservatism, and personal rights and liberties, and denied any ideological affinity with political Islam. Party documents defined the AKP's approach to religion as sensitive to religious values. However, the AKP identified with a populist anti-elitism and people-centric appeal from the beginning, framing its anti-establishment stance through a mixture of conservative and liberal ideas, such as social justice, moral values, social norms, individual freedoms and human rights. 
The government also chose not to promote public policies with potential religious implications through the Islamic doctrine. Two legislation proposals for the re-criminalisation of adultery and higher education regulation (see below) were meticulously framed in a language of equal rights and freedoms. Since the proposal on the re-criminalisation of adultery was inspired by Islamic doctrine, it was met with a public outcry by the opposition party Republican People's party (CHP), seen as the representative of the secular establishment, women's organisations and the EU (Demirler and Gümüş 2004). However, the government responded by emphasising the centrality of the 'traditional and national values of the Turkish society' in its decision, claiming that the re-criminalisation of adultery was a response to the demands of 'the Anatolian' (read 'ordinary') women (Ilkkaracan 2008), and not to religious requirements. The then Foreign Minister Abdullah Gül even compared the question of adultery to Ireland's abortion policy and asked the EU to reconsider its opposition to a nationally sensitive issue (Hale and Özbudun 2011, 71). However, when the AKP did not succeed in convincing groups critical of the legislation, it withdrew the proposal.

Similarly, in 2004, the government sought to amend higher education regulation in order to allow the graduates of religious Imam Hatip High Schools to compete on an equal footing with the graduates of regular high schools in the nationwide exam for public universities. When the then President Ahmet Necdet Sezer - a staunch secularist - vetoed the law, the AKP withdrew it from the agenda. Notably, the then Prime Minister Tayyip Erdoğan avoided appealing religious sentiments by stating that:

Those parents who sent their children to vocational schools did not support the issue enough. The society did not stand up against the pressure. We could have sent the bill twice. But are you ready to pay the price? There is a price attached to it. As a government, we are not ready yet to pay the price (cited in Hale and Özbudun 2011, 70).

The price that Erdoğan implied was the potential reaction from the still dominant secular establishment, particularly the military. Erdoğan appealed to the parents who chose religious schools but pragmatically chose to raise its anti-establishment critique asking 'the ordinary people' to resist the secular establishment. This anti-establishment critique was framed through a reference to individual rights and democracy and not in defence of confessional education. Without a substantial electoral majority to challenge the establishment, the government did not utilise religion to frame its populist anti-elitism and people centricism.

\section{The second term (2007-2011)}

In the 2007 elections, the AKP expanded and consolidated its electoral support with almost half of the votes. On the one hand, the AKP built an image of itself as the victim of the secular establishment by focusing on several political challenges: the military's e-memorandum, the veto of Abdullah Gül's presidential bid and the attempt to ban the AKP through the Constitutional Court (Jenkins 2008). On the other, it continued to position itself on the side of 'the people' claiming to be the champion of democratisation and freedoms thanks to the political reforms undertaken between 2002 and 2005 (Özbudun 2007; Patton 2007).

Empowered by an expanded majority in its second term but convinced of the mounting political challenges, the AKP began to use religion in its populist attack against the secular establishment. The apparent change first appeared on the issue of the headscarf debate, which had long been a fault line between secularists and conservatives/Islamists in Turkey. In 2008, Erdoğan declared that banning headscarves in public institutions constituted 'a violation of 
freedoms where $99 \%$ of the population is Muslim' (Radikal 2008). He dismissed criticisms by asserting that religious symbols and icons cannot be banned. In contrast to the first term, when the rights of the individual - not the majority's 'Muslim identity' or Islam's requirements were often-quoted to defend the government's position on public policies, Erdoğan's framing of the headscarf issue was a direct attack on the establishment by appealing to the sense of Muslim victimhood.

The discursive transformation from emphasis on individual rights to Muslim identity was a turning point also for public policies, which became more majoritarian and imposed topdown. The government took an antagonistic position when the opposition party CHP, the Supreme Court, the Higher Education Council and certain universities voiced objections to the revoking of the headscarf ban. Despite the ongoing objections and the divided public opinion on the issue, the government passed the constitutional amendment with the support of a narrow parliamentary majority.

The AKP also started to use religious tenets to siphon off political grievances and to construct an imagined unity of the people. The attempted reconciliation policies towards ethnic and religious minorities, Kurds and Alevis, exemplify how the AKP initially sought to appeal to these groups as their 'true representative'. In this sense, the AKP considered Sunni Islam as the most useful instrument to bring together cross-class and cross-ethnicity groups against the secular establishment. The government's emphasised the common culture and centuries of coexistence between Alevis and the majority Sunni communities (Soner and Toktaş 2011). However, 'the Alevi initiative' only offered symbolic gestures towards the Alevi minority (Subasi 2010). The government's approach remained assimilationist and sectarian promoting the majority religion without accommodating Alevi demands, such as legal status and the end of compulsory Sunni Islam teaching at schools.

The government's initial policy towards Kurds was also based on the idea of shared religion and the collective Ottoman past in an attempt to eliminate demands for ethnic pluralism (Saraçoğlu 2011). Accusing the secular establishment, which prioritised Turkish national identity over religious and ethnic identities, the AKP claimed to be on the side of Kurds as their true representatives who were also seen as victims of the 'Kemalist secular elites' alongside the conservative Anatolian majority. In a 2011 election rally in Diyarbakır, Erdoğan's address to the Kurdish minority accused the secular state of inflicting 'the common ill', the secular Turkish national identity:

Everything denied to you was denied to us as well. Mosques were converted into barns and warehouses by the CHP. The same party also banned religious books. I, your brother, was imprisoned for reading a poem in Siirt. I have heard the outcry of Diyarbakir prison from Istanbul. I struggle for the same thing. I know very well what denial and assimilation are. But, both are over. I know the tears of a [Kurdish] mom who cannot talk to her son in her language at Diyarbakir prison (as cited in Saraçoğlu 2011, 50).

The policy towards Alevis and Kurds aimed to construct the myth of a monolithic nation and a unified people by attacking Turkey's secular codes and replacing them with catch-all religious references. However, not very different from the secular establishment, the AKP also denied diversity, emphasising an imagined unity based on majority religion as common ground, while ignoring demands for ethnic and religious pluralism. In doing so, the AKP sought to expand the category of 'the pure people' as victims of the secular establishment. These attempts to create a unified front against secular elites also aimed to expand the AKP's electoral bloc to act as the only 'genuine representative' of all groups. The ultimate goal was to undermine all 
competing claims for representing Kurds and Alevis by actors such as the PKK or the opposition parties HDP and CHP.

The strategy towards Kurds has been successful only to a certain degree as the AKP gained the support of conservative Kurds. However, the majority of Alevis and left-leaning Kurds refused to become part of 'the imagined' people based on the unity of the ummah. The sectarian limits of this approach together with novel political challenges provided the AKP with the opportunity to use religion to define in- and out-groups as it further consolidated its power for another term.

\section{The third term (2011-2015) and beyond}

Following the victories of the 2010 constitutional referendum, and the 2011 and 2014 general and presidential elections, the AKP has become Turkey's dominant party with its de facto leader Erdoğan becoming the first president elected by popular vote. With a third term in office, the essence of the AKP's populism remained intact in the party discourse and its policies. However, the lines between 'the virtuous people' and 'the elites' have been redefined as the government's populist anti-elitism evolved into clear anti-pluralism (Yabanci 2016a, 599). The role of religion in the AKP's discourse, policies and alliances has evolved from being a unifying tool in its earlier attempts to craft the imagery of unified people across the borders of class and ethnicity towards a divisive instrument creating or deepening ethnic, national, religious and partisan fault-lines. During this period, the AKP also faced increasing political challenges by various democratic dissident groups demanding restoration of democratic norms and practices including 2013 Gezi protests, renewed armed conflict with PKK, a military coup attempt, and a narrowly passed constitutional referendum introducing de facto regime change (for a detailed summary of developments, see Yabanci 2016d). Religion became an instrument with which to dismiss or overcome all these challenges and to label, disenfranchise and oppress groups who do not fit 'the people' that the AKP claims to represent.

First, the AKP has replaced its 'conservative democracy' agenda with the goal of establishing a 'New Turkey'. At the political level, the New Turkey project has been defined by the majoritarian power abuse and the replacement of the parliamentary regime with a presidential system without checks and balances. At the societal level, 'New Turkey' has been validated by polarisation and a top-down promotion of public Islam to define the 'acceptable' people and nationhood. The use of arguments and symbols inspired by Sunni Islam has been interwoven with a nationalist and neo-Ottoman civilisational discourse promoting 'Muslim nationalism' (White 2014). The new model of religious-national identity, however, does not exalt Islam per $s e$; it sacralises 'the eternal Turkish nation' as referred by Erdoğan.

Through the use of religious discourse, the AKP has increasingly aimed to render ideological, ethnic and religious dissent unacceptable. Religious appeals have been utilised to declare political dissenters as immoral and anti-Islamic, and thereby excluded from the category of 'the people' or the nation. To divert public attention away from the political demands of the 2013 Gezi protests and to engender negative public opinion about the demonstrators among a conservative electorate, the government deliberately fabricated allegations depicting protestors as disrespectful of religion, including accusations of drinking beer within the premises of a mosque and attacking a veiled woman. The AKP has also sought to target specific dissident groups and individuals as 'un-Islamic'. For instance, the government publicly questioned the prolonged hunger strike of Nuriye Gülmen and Semih Özakça - who protested against their dismissal under the state of exception rules following the 2016 coup attempt - as being contrary to Islamic requirements. 
Regarding the Kurdish minority, the AKP attempted to maintain its utilisation of Sunni Islam to brush aside Kurdish claims and uphold the imagined unity under one religion. For the 2015 electoral campaign, Erdoğan delivered speeches to ask electoral support in the Kurdish southeast with a copy of the Quran in Kurdish in his hand. But when the pro-Kurdish opposition party HDP became a vocal critique of the Erdoğan's vision of presidential system and proved its potential as a threat to the AKP's monopolisation of the executive in June 2015 election, Kurds who did not vote for the AKP went from partners in the anti-establishment coalition to traitors. When the armed conflict resumed with the PKK, some government representatives sought to convince the conservative Kurds by implying that some insurgents might not be Muslims (Hürriyet 2015).

In the repressive atmosphere of the post-coup period, religious norms and ideas have been manipulated and co-opted by the AKP to fend off criticisms even from Islamist and conservative circles. When a group of Islamist intellectuals organised the civic movement Hak ve Adalet Platformu (Rights and Justice Platform) to reject the 2017 constitutional referendum, the government labelled them on the side of the secular and Kurdish opposition against the people and the national will (Yabanci 2017). Erdoğan himself declared that the Islamist intellectuals chose the side of the PKK and the Gülenist network. Several opinion articles and TV debates in AKP-controlled media discredited the critique of the Islamist and conservative circles and sought to promote the foreseen presidential system as compatible with Islamic governance (e.g. Arican 2016). They uniformly promoted Erdoğan's presidency, arguing that Islam welcomes a leader who is the defender and saviour of the people.

Furthermore, the government imposed public policies and top-down interventions on the role of religion in public and private life, such as restrictions on the sale and consumption of alcohol, family planning and abortion, and women's participation in the workforce. These policies were complemented with the promotion of religious classes in public schools, and an exponential increase in the number of Imam Hatip religious schools, private and state-funded Quran courses, and mega-mosque building projects with the declared aim of 'raising a pious youth' (Kaya 2015; Somer 2015) loyal to religious and national values as the 'acceptable citizenry' untainted by divisions and dissent.

During its third term, the AKP also pursued a systematic policy of institutional empowerment towards the main religious authority - the Directorate of Religious Affairs (Diyanet). Although the Diyanet was historically used by the state to pacify and manage religion in the public sphere, after 2011 it became a mouthpiece of the AKP for political propaganda and the promotion of public policies that increased the influence of Islam in both politics and society (Cornell 2015).

The Diyanet has not promoted religion for its own value but in order to transmit and expand the reach of the AKP. Before 2014 local elections, the Diyanet declared that freedoms can be restricted under some circumstances, implicitly supporting the media bans that the AKP imposed during that time. Similarly, during the 2015 electoral campaign, imams offered sermons asking mosque attendees to vote for 'Muslims' (Cornell 2015). Most recently, mosques and prayers were used to stir political support in the aftermath of the July 2016 coup. A few hours after the coup attempt, the Diyanet ordered all mosques across Turkey to read the salah (a special prayer read from mosques on Fridays and also to announce funerals) day and evening. Salah were followed by country-wide calls from mosques on all people 'in the love of God and Prophet' to go out on the street and stand against the coup (Esen and Gumuscu 2017, 65). 
The Diyanet disseminated and promoted Erdoğan's call for the people to protest against the military while religiously praising the civilians killed by the putschists. The use of mosques and prayers decoupled the anti-coup resistance from a democratic reaction and sacralised it as a religious duty. More recently, Diyanet-appointed imams also used the Friday sermons to mobilise the electorate to vote in favour of the 2017 constitutional referendum on the presidential system (Sezgin 2017). Labelling those who rejected the proposed changes as 'traitors', the Diyanet once again acted as a partisan agent to mobilise the masses in favour of the constitutional amendment.

As the AKP has faced increasing challenges in the form of either popular dissent against its power grip or an illegal attempt by a military junta, both religious appeals and religious institutions have become instrumental in sacralising politics, the leader, the national will and 'the people'. The AKP's approach towards Islam rendered it a malleable tool to divide society in mutually-exclusive camps based on partisan allegiance. Other cleavages, Kurdish-Turkish, secular-conservative, Alevi-Sunni- were formatted to deepen the polarisation between 'the people' versus the rest. Religion is co-opted to legitimise the AKP's majoritarian and increasingly authoritarian rule and helped the party maintain the relevance of a moralist and populist antagonism between 'the good people' and 'the enemies of the nation'.

\section{The Democratic Party for Macedonian National Unity (VMRO-DPMNE)}

\section{The first term (2006-2008)}

The first VMRO-DPMNE government did not embrace populism's monist and moralistic depiction of politics as a struggle between 'the people' and the establishment. The VMRODPMNE combined a pro-EU attitude with a conservative ideology (Vecer 2007). The party programme 'Doctrine' listed faith, church, family and tradition among its main guiding values. As stated by the then speaker of the parliament Trajko Veljanovski, the government praised Christian Orthodoxy and its 'highest representative', the Macedonian Church's (MPC) guardianship over national and cultural identity: 'we shall overcome our differences together, as the state and the church, and unite in our goals to preserve our national identity, our state and our church' (Assembly 2008). The VMRO-DPMNE promoted a narrative according to which the church is under pressure within the Orthodox world, similar to the one faced by the independent Macedonian state, implying that the name dispute with Greece and the EU, and the MPC's struggle for recognition are the two sides of the same coin.

However, the VMRO-DPMNE's praise for religion did not take a populist, anti-elitist and anti-pluralist character during this period. To the contrary, public policies promoting the role of Christian Orthodoxy were balanced by policies addressing the freedoms of ethno-religious communities. The 'Doctrine' of the party even welcomed religious minorities:

We consider religious tolerance essential to life in multicultural Macedonia. God is one, but we celebrate him differently. Our churches, our mosques and synagogues are our spiritual temples. The VMRO-DPMNE is a platform through which Christians, Muslims and Jews are active (VMRO-DPMNE 2006).

At the policy level, when the government introduced new public holidays for the Christian Orthodox majority, it also declared International Roma Day, Day of the Albanian Alphabet and Day of Education in the Turkish Language as public holidays (Vecer 2006). In 2007, the government introduced a new law assuring autonomy to all religious communities and guaranteeing their equality before the law. 
Yet, the VMRO-DPMNE started to develop close relations with the MPC early on. In 2007 , it chose to celebrate its $17^{\text {th }}$ anniversary at the vast monastery complex of St. Pantelejmon. The celebration hosted the MPC's high-level delegation, including the Archbishop, as the guest of honour. Several church dignitaries were invited to local celebrations, appearing alongside VMRO-DPMNE representatives in an apparent gesture supporting the government in the eyes of the electorate. However, given its overall neutral position towards the Muslim Albanian and Christian Orthodox groups, the VMRO-DPMNE still avoided using religion for political gains during its first term in office. Its attitude towards religion as the basis of Macedonian identity highlighted its conservative ideology, in fact resembled European Christian Democratic parties.

\section{Second term (2008-2011)}

The elections in 2008 brought a landslide victory to the party with the support of almost half of the electorate. However, the VMRO-DPMNE found itself unable to address mounting economic challenges. The government came under increasing pressure to deliver its promises based on a neoliberal agenda, which only opted for tax cuts for upper-income groups and restricted labour rights, leaving it unable to deliver the promised economic prosperity or address the widening income inequality.

During the second term in office, the VMRO-DPMNE turned to 'overzealous religious fervour' as an instrument to articulate revanchist anti-elitism (Osservatorio Balcani e Caucaso 2011). On the $20^{\text {th }}$ anniversary celebrations of the party, Nikola Gruevski announced that 'the VMRO-DPMNE is a party of the people and not of the elite', implying that the socialist main opposition party is part of the political establishment dating back to the communist regime. Religion and religious symbolism gradually became part of the propaganda for the constant mobilisation of party supporters against the parliamentary opposition, especially when it objected to certain public policies.

A case in point is the VMRO-DPMNE's polarising attitude on the public role of religion, mostly in the form of mega-church construction projects. In 2008, the government introduced the Skopje 2014 project, including a massive new church complex in the main square of Skopje and other reconstruction and renewal projects. It also began the restoration of the Monastery of Treskavec in Prilep and the Monastery of Lesok, destroyed during the 2001 ethnic conflict with the Albanian community (VMRO-DPMNE 2008). These projects were promoted to demonstrate VMRO-DPMNE's allegedly 'hardworking', 'people-oriented' and respectful attitude towards the national values in opposition to the previous 'lazy' and 'self-interested' elites.

However, Skopje 2014 soon became a deeply polarising project since many people perceived it as an attempt to 'rewrite history' and exalt Macedonian nationalism by erasing communist and Ottoman-era symbols and monuments (Reef 2017). Moreover, the project's lack of transparency, massive cost to taxpayers and corruption allegations raised public scepticism. In March 2009, a group of students protested, demanding an expert evaluation of the construction plan and more transparency in the bidding process. The government argued that the project was about defending the values of the church - that is, the values of the Macedonian people while also accusing the protesters of being followers of the decadent and immoral remnants of the communist establishment (Global Voices 2009). The government also claimed that since it had won the popular mandate it had the right to use public funds to build a Christian temple (Vecer 2009). 
One of the opponents of the mega-church projects was the Democratic Union for Integration (DUI), the VMRO-DPMNE's minor coalition partner, which is the largest representative of the Albanian community. Despite the intra-governmental discord, the then Deputy Prime Minister Vasko Naumovski argued that the struggle was between religious people "who want a church' and 'others who probably want a mosque'. The government even organised a counter-protest to display popular support for Skopje 2014 with ostensible support from church dignitaries. Carrying religious symbols, such as flags and icons, counter-protesters physically and verbally attacked the protesting students calling them 'a tribe of gays and atheists' (Global Voices 2009).

The VMRO-DPMNE's second term was also marked by a strategic move against the Constitutional Court to strengthen the government's popular support through religious appeals. In 2009, the Court annulled the law on the provision of confessional education in state primary schools. In its decision, the Court argued that each religious community already had the freedom to organise religious teaching outside the formal education system in line with the principle of separation between church and state (Karajkov 2009). It also claimed that religious classes in state schools would 'add another layer of academic separation, beyond the existing linguistic barrier' between the Macedonian Slav and Albanian students (Fontana 2015, 76). The Court's decision was supported by the opposition parties as well as by the then President Branko Crvenkovski (Karajkov 2009). However the question of religious education in public schools unleashed a divisive debate over Macedonian identity.

In its rebuttal of the Court's decision, the VMRO-DPMNE sought popular support by framing its position as defending Macedonian religious and national values. On the one hand, by emphasising the role of Christianity as an integral part of the Macedonia's 'distinct' Slavic and Orthodox national identity and state, the government capitalised on the opportunity to contest the Bulgarian, Serbian and Greek claims that deny the existence of the Macedonian nation and state since the declaration of independence in 1991. The VMRO-DPMNE sought to stir nationalist feelings through religious identity. But it only excluded the Muslim Albanian community from religious definition of the nation (Clark 2014).

On the other hand, the VMRO-DPMNE sought to strengthen its electoral base by gaining the sympathy of the public who demanded the continuation of religious education classes. According to 2008 public opinion surveys, almost half of the population, including a significant percentage of Albanians, favoured religious education in state schools (Markovik et al. 2013, 29). Convinced of the opportunity to expand its popular support, the government dismissed the Court's decision as a political move influenced by the main opposition party, the Social Democratic Union of Macedonia (SDSM). Then, it demanded the re-introduction of religious education by promising a constitutional amendment (Balkan Insight 2009). This was also an opportunity for the VMRO-DPMNE to make potential electoral gains against the SDSM. While it asserted itself as the defender of religion and national identity, it dismissed the socialist opposition party's objections by referring to the old establishment -Yugoslavia- as 'the remnants of the atheist dictatorship' for acting against the people's wishes (Fontana 2015).

Finally, the VMRO-DPMNE established a close alliance with the Macedonian church. The MPC ardently criticised the Constitutional Court and supported the introduction of religious education in primary schools (Utrinski Vesnik 2009). However, the relations between the VMRO-DPMNE and the MPC were established on a basis of mutual accommodation. In 
return and to maintain a good relationship with the MPC, the VMRO-DPMNE provided public funds to theological higher education institutions (Utrinski Vesnik 2011).

\section{The third term (2011-2014) and beyond}

Following another electoral victory in 2011, the VMRO-DPMNE glorified the majority and used the election results as the ultimate justification of its moral and political legitimacy. However, signs of corruption and the wasting of public funds emerged in relation to the government's Skopje 2014 project alongside increasing discontent with its attempts to monopolise legislative processes and the state bureaucracy.

In its third term, the VMRO-DPMNE started to use a more polarising populist political discourse. The public speeches of party leader Nikola Gruevski were dominated by conspiracy theories and attacks against ambiguously defined enemies of Macedonia. For instance, he stated that donations to the new church would 'contribute to defend the family from crooked values that "some" are promoting, and from the attacks towards the traditional and moral values that support our family and people in moments of major temptation and danger' (VMRODPMNE 2014).

The speeches of the party's heads followed Gruevski's monist and moralistic discourse, aiming to boost religious and nationalist fervour. The VMRO-DPMNE particularly sought to mobilise youth by utilising religious references to build partisan support and stir nationalist sentiments. In 2012, the leader of the party's youth branch Dime Spasov redefined its mission by stating that the Macedonian youth is 'God's Army blessed by the Macedonian Archbishop and the leadership of President Nikola Gruevski'. He also added that 'Christianity, besides the preservation of people's spirit, is, for us Macedonians, a protector and supporter of our identity' (RFE 2012).

From the perspective of the government, equating Christian Orthodox identity with national identity served a dual function. First, through the promotion of public religion, the VMRO-DPMNE maintained the support from both the MPC and the conservative electoral bloc. The VMRO-DPMNE followed the 'recipe of the church' in its policies (Fama 2013). It proposed legal amendments to restrict abortion, despite an outcry by civil society and the main opposition party (Marusic 2013), and a constitutional ban on same-sex unions. Perhaps more importantly, neither the church nor the government defended these policies using religious doctrine, for instance the sanctity of life. Instead both the MPC and the government sought to curb civil rights and the rule of law on the basis of a so-called urgency to safeguard 'the nation' by protecting fertility and society, arguing that 'those who do not care about fertility are not patriots' (24Vesti 2013).

During this period, the VMRO-DPMNE also introduced laws and regulations banning the sale of alcohol in the evening, putting controls over the opening times of pubs, and imposing religious ceremonies to celebrate secular events, such as using the main church to officially open the 2012 academic year of Skopje University (Beyond Europe 2017). Mega church-building projects were further expanded with new plans to restore 16 medieval churches and monasteries, and to build a new gallery of Christian icons (VMRO-DPMNE 2014). The policy of hyper-production of Orthodox religious sites intensified the ethnic and religious exclusion of minorities in Macedonia. Opening ceremonies for new monuments and churches were turned into pro-government rallies, presented as proof of the party's respect for personal freedoms (VMRO-DPMNE 2015). 
In return, church hierarchs, including the archbishop of the MPC himself, often accompanied government officials during ostentatious opening ceremonies of new monuments and churches as a show of support for the VMRO-DPMNE. The MPC even promoted and justified the government's church construction initiatives on its website, openly offering praise to its efforts to promote religion (MPC 2015, 2016).

Second, the VMRO-DPMNE's excessive leaning on religious appeals and symbolism helped it assert 'a strong cult of infallibility, invincibility and uncompromising position' against the parliamentary opposition, dissident groups and minorities (Petkovski 2014, 11). Attempts to weaken democratic procedures were masked by VMRO-DPMNE's claim to valorise the will of the people, and restore both tradition and an endangered national unity in which religion had a critical legitimising role. The government dismissed the evident corruption favouring the network of the loyal business circle around the VMRO-DPMNE by the opposition and civil society and criticisms of its undemocratic interventions by re-producing consecutive crises through the conspiracy of threats to the people (BIRN 2017). 'The people' was, however, more and more defined through ethno-nationalism and Christianity and excluded Albanians. When ethnic tension resurfaced in Kumanova in 2015 as a result of polarisation, VMRODPMNE chose to escalate it by declaring Albanians as' terrorists'. Crises helped VMRODPMNE conceal its incompetency, corruption and deteriorating economy due to the heavy cost of Skopje 2014 (Günay and Dzihic 2016).

When political crises spiralled, the government resorted to early elections as the ultimate strategy to reassert 'the people's sovereignty'. Although early elections in 2014 brought a victory for the VMRO-DPMNE, growing civic unrest escalated further with a crisis surrounding a wire-tapping scandal and street protests in 2015 and 2016 (Taleski 2016). After another round of snap elections in 2016, which gave the VMRO-DPMNE a new electoral victory, the party, and particularly its leader Gruevski, continued to rule through a conspiracy-driven discourse, which was anti-Albanian aimed to provoke the Slavic Orthodox majority further and to distract the party's constituency from 'the systematic abuse and manipulation of institutions' under VMRO-DPMNE rule (Taleski 2016).

\section{Conclusion: populism and co-opting 'the religion'}

Our study delivers empirical evidence to support the argument that while ruling populist parties emerge within democratic systems, in the long-term they have the potential to transform and challenge democracy itself (Arditi 2007; Müller 2016). Our major contribution illustrates how religion can be used as a political instrument in the hands of ruling populists to overcome national crises, marginalise dissent and justify attacks on democratic institutions and minorities.

The empirical discussion shows that, despite the different political and historical contexts of the two countries, the long-term ruling populist parties in Turkey and Macedonia followed a similar populist strategy with regards to religion. The two parties followed parallel paths in their timing and utilisation of the predominant religions. During their first term in office, several pro-EU political and economic reforms allowed them to build domestic and international credibility, and to challenge existing power relations as outsiders to the establishment.

Once they achieved landslide electoral victories, religion was initially adopted as a unifying instrument above class, ethnic, religious and other divisions to further expand their appeal 
to all people who had suffered under the establishment (secular parties and the military in Turkey, and communist rule in Macedonia). Since populist parties claim that only they mirror the people's will, in countries where the majority belongs to a single faith, religion has a catch-all potential to keep alive the illusory idea of a united and homogeneous people. The AKP has used the rhetoric of shared religion as the major component in its Alevi and Kurdish reconciliation policies that were designed primarily as an attempt to expand the AKP's electoral bloc in its assault against the secular establishment. Similarly, the VMRO-DPMNE initially promoted religious rights for all ethnic and religious minorities, avoiding populist polarisation between the Orthodox Christian Slavs and Muslim Albanians. Both parties have become successful in articulating a claim to 'the unity of the people' through religion and incorporating minorities in their electoral coalition.

In their latest terms, political challenges have started to impinge on the AKP and the VMRO-DPMNE's popular support. Religious appeals have been extensively utilised to create and shape societal and political cleavages, and to replace their weakened democratic legitimacy with religion to justify and sustain both incumbents' hold on power. The majority religion has created and validated a dichotomy between friends and foes. The 'enemies', who are blamed for conspiring against 'the people', have been redefined to include not only the previous ruling elites but also dissidents and minorities, and created a pro- and anti-government cleavage. In Turkey, as the Alevi and Kurdish communities and the political opposition refused to submit to a state monopolised by the AKP, they became 'the enemies of the national will', while the AKP endowed national identity with religious references. Similarly, the VMRO-DPMNE's initial support for an all-inclusive form of religious freedom gradually turned into the dominance of Christian Orthodoxy. Religious identity has become a norm defining the Macedonian nation that excludes not only Albanians but also the main opposition party, LGBTQ groups and civil society, all lumped together as the remnants of the atheist establishment and 'the enemies of the state'. Simply put, both governments have propelled an imaginary people as 'acceptable' citizens based on religious and political criteria: being a devout Sunni Muslim or Orthodox Christian and a supporter of the government. Being a political or religious dissenter has become sufficient grounds for exclusion from the categories of 'the people' and 'the devout'.

In parallel with the rapid decline of democratic conduct and the increase in authoritarian tendencies in both countries, religion has also proved to be a handy instrument in undercutting rising dissent and a substitute for weak democratic credentials, particularly when facing political and economic challenges. When they faced political and economic challenges that could potentially oust them, the AKP and the VMRO-DPMNE tailored religious appeals, policies and institutions to forge a moral high ground, and to support their claim of being the only true representatives of the people's will. In these two profoundly religious and conservative societies, any form of dissent has become equal to an attack on the majority religion.

Finally, both populist parties have also incorporated major religious institutions, the Diyanet and the MPC, into their populist politics in an attempt to expand a supportive coalition towards the government. In Turkey, relations have remained top-down. The Diyanet has historically lacked institutional autonomy from the state, so it was quickly co-opted to become a mouthpiece for the government when the AKP expanded its control over state institutions. In contrast, the VMRO-DPMNE had to follow a mutual accommodation strategy and make concessions to ensure that the independent and powerful Orthodox Church remained on its side. 
Overall, the ruling populists in Turkey and Macedonia have gradually incorporated religious references into their existing populist appeals not because they lacked electoral success, or because they were in search of a new ideology. Instead, the dominant faiths in both countries - Sunni Islam and Christian Orthodoxy - have become one of their key instruments to build consent for an increasingly authoritarian-leaning populism. In this sense, this study questions the assumption that there are differences between the political roles of Islam and Christianity, regardless of which, religion has proved to be a useful instrument to attack enemies of the state in the name of the people.

Yet, our study also demonstrates the limits of the populist hijacking of religion and religious institutions. As democratic credentials are systematically undermined and the legitimacy of the ruling populists is questioned, the 'religionisation' of politics has drawn criticism in Turkey and Macedonia, and even triggered a counter-reaction among some of the traditional supporters and allies of populists. In Turkey, the AKP has pushed the instrumentalisation of religion to its limits by justifying its unchecked presidential system based on Islamic credentials and by labelling democratic dissent as anti-Islamic. In the April 2017 constitutional referendum, these attempts failed to convince certain Islamist circles and a considerable part of the AKP's ultra-nationalist ally, the Nationalist Action Party (MHP), which is a long-term promoter of the Turkish-Islamic synthesis as the basis of national identity.

In Macedonia, the VMRO-DPMNE has manipulated religion to draw ethnically exclusive boundaries of 'the people', to reinvent the nationhood and to stigmatise the political and civic opposition, labelling it as an opponent of religious-national values. However, following the 2015 political crisis marked by corruption and wiretapping scandals, this strategy failed in 2017 when the VMRO-DPMNE was ousted without the support of its long-term Albanian coalition partner DUI (Mejdini 2017). Macedonia's long 'authoritarian consociationalism' (Spaskovska 2014) came to an end while the VMRO-DPMNE's attempt to push nationalist sentiments, based on the majoritarian Slavic Christian Orthodox identity, has been halted, for now. In this sense, the dual functions of religion - its catch-all potential to craft a 'homogenous people' and its use to justify the antagonism of 'the people versus the elites' - are hardly sustainable in the long-term. 
Forthcoming in Religion, State and Society

\section{References}

Albertazzi, Daniele, and Duncan McDonnell. 2008. Twenty-First Century Populism: Houndmills: Palgrave.

Arditi, Benjamín. 2007. Politics on the Edges of Liberalism. Edinburg: Edinburgh University Press.

Arican, Musa Kazim. 2016. 'İslami düşünce açısından başkanlık sistemi [Presidential System from the Perspective of Islamic Thinking]'. Yeni Şafak. November 28. http://www.yenisafak.com/.

Assembly. 2008. 'Speech of President of the Assembly'. Skopje, 4 October. http://sobranie.mk/.

Balkan Insight. 2009. 'Macedonia Plea for Religion in Schools'. 20 May. http://www.balkaninsight.com.

Berger, P. 1999. The Desecularization of the World. Washington, D.C. : Eerdmans Publishing Co.

Beyond Europe. 2017. 'The Political Crisis in the Republic of Macedonia'. https://beyondeurope.net/.

BIRN. 2017. Skopje 2014 Uncovered. https://birn.eu.

Çarkoğlu, A., and Ersin Kalaycioglu. 2009. The Rising Tide of Conservatism in Turkey. New York: Palgrave.

Casanova, José. 2007. 'Rethinking Secularization. In Religion, Globalization, and Culture, edited by Lori Beaman and Peter Beyer, 101-20. Brill.

Clark, James D. 2014. 'The Conflicts of Identity'. Central Eastern European Review 8 (1): 41-67.

Demirler, Derya, and Pinar Gümüş. 2004. 'TCK Degisirken... [While the Criminal Code Is Shaping...]'. Feministe. http://www.feminisite.net.

Diamond, Larry. 2015. 'Facing Up to the Democratic Recession'. Journal of Democracy 26 (1): 141-55.

Esen, Berk, and Sebnem Gumuscu. 2017. 'Turkey: How the Coup Failed'. Journal of Democracy 28 (1): 59-73.

Fama. 2013. 'Поповска За Законот За Абортус - Рецептите На Владиката Петар Нема Да Поминат [Popovska on the Abortion Law - The Recipes of Bishop Petar Should Not Pass]'. 29 May. http://www.fama.mk/.

Filc, Dani. 2009. The Political Right in Israel: Different Faces of Jewish Populism. Oxon: Routledge.

Fokas, Effie. 2006. 'Greece: Religion, Nation and European Identity'. In Citizenship and Ethnic Conflict, ed. Haldun Gulalp. Oxon: Routledge.

Fontana, Giuditta. 2015. 'State-Building and Religious Education in FYROM'. In Policies and Politics of Teaching Religion, ed. Theodor Hanf and Karim El-Mufti, 69. Bloomsbury Publishing.

Global Voices. 2009. 'Macedonia: Student Protests End with Violence'. https://mk.globalvoices.org.

Günay, Cengiz, and Vedran Dzihic. 2016. 'Decoding the Authoritarian Code. Southeast European and Black Sea Studies 16 (4): 529-49.

Hadiz, Vedi R. 2014. 'A New Islamic Populism and the Contradictions of Development'. Journal of Contemporary Asia 44 (1): 125-43.

Hale, William, and Ergun Özbudun. 2011. Islamism, Democracy and Liberalism in Turkey. London: Routledge. 
Hürriyet. 2015. AK Partili Burhan Kuzu başkan da olmadı [AKP representative Burhan Kuzu could not become the president of the constitutional commission]. www.hurriyet.com.tr. Ilkkaracan, Pinar. 2008. 'How Adultery Almost Derailed Turkey's Aspiration to Join the EU'. In Deconstructing Sexuality in the Middle East, 41-64. Hampshire: Ashgate.

Jati, Wasisto Raharjo. 2013. 'Radicalism in the Perspective of Islamic Populism'. Journal of Indonesian Islam 7 (2): 268-87.

Jenkins, Gareth. 2008. 'Turkey’s Latest Crisis'. Survival 50 (5): 5-12.

Kalyvas, Stathis N., and Kees van Kersbergen. 2010. 'Christian Democracy'. Annual Review of Political Science 13 (1): 183-209.

Karajkov, Risto. 2009. 'The Government vs the Court'. Osservatorio Balcani e Caucaso. https://www.balcanicaucaso.org/.

Kaya, Ayhan. 2015. 'Islamisation of Turkey under the AKP Rule'. South European Society and Politics 20 (1): 47-69.

Lefort, Claude. 1988. Democracy and Political Theory. Cambridge: Polity.

Loizides, Neophytos G. 2009. 'Religious Nationalism and Adaptation in Southeast Europe'.

Nationalities Papers 37 (2): 203-27.

Markoviḱ, Nenad, Vladimir Misev, Marko Troshanovski, and Misa Popovic. 2013. Political Culture in Macedonia. Skopje: Friedrich Ebert Stiftung.

Marusic, Sinisa Jakov. 2013. 'Macedonia Adopts Controversial Abortion Law'. Balkan Insight. http://www.balkaninsight.com.

Marzouki, Nadia, Duncan McDonnell, and Olivier Roy, eds. 2016. Saving the People. Oxford: Oxford University Press.

Mejdini, Fatjona, 2017. DUI Split Stopped Macedonia's Gruevski Forming Government. Balkan Insight. http://www.balkaninsight.com.

MPC. 2015. 'Sanctification and Laying down a Cornerstone for a New Temple in the Settlement Dame Gruev'. 5 December. http://www.spe.org.mk. . 2016. 'Sanctification and Laying down a Cornerstone to Erect a Cross in Municipality of Butel'. 27 February.

Mudde, Cas. 2007. Populist Radical Right Parties in Europe. Cambridge: CUP.

—. 2017. 'We Are Thinking About Populism Wrong'. Huffington Post. March 20. http://www.huffingtonpost.com.

Mudde, Cas, and Cristóbal Rovira Kaltwasser. 2012. Populism in Europe and the Americas. Cambridge: CUP. 2017. Populism: A Very Short Introduction. Oxford : OUP.

Müller, Jan-Werner. 2015. 'Parsing Populism' Juncture 22 (2): 80-89.

- 2016. What Is Populism? University of Pennsylvania Press.

Osservatorio Balcani e Caucaso. 2011. 'In Macedonia, Clashes Over Religious Symbols, Again'.

Oxhorn, Philip. 1998. 'The Social Foundations of Latin America's Recurrent Populism'. Journal of Historical Sociology 11 (2): 212-46.

Özbudun, Ergun. 2007. 'Democratization Reforms in Turkey, 1993-2004'. Turkish Studies 8 (2): 179-96.

Patton, Marcie. 2007. 'AKP Reform Fatigue in Turkey' Mediterranean Politics 12 (3): 33958.

Petkovski, Ljupco. 2014. 'Who Are Gruevski’s People?' NGO Info-Center, Skopje. http://nvoinfocentar.mk/

Radikal. 2008. 'Erdoğan: Sembole Yasak Konulamaz [Erdogan: Symbols Cannot Be Banned]'. January, 15. Radikal. http://www.radikal.com.tr/.

Reef, Paul. 2017. 'Macedonia's Colourful Revolution and the Elections of 2016.' Südosteuropa 65 (1): 170-182. 
RFE. 2012. 'Dime Spasov: Of Values and Road Signs'. 17 January. http://umsdenes.blogspot.mk.

Roy, Olivier. 2016. 'Beyond Populism'. In Saving the People, edited by Nadia Marzouki, Duncan McDonnell, and Roy, 185-202. Oxford: Hurst \& Co.

Saraçoğlu, Cenk. 2011. 'İslami-Muhafazakar Milliyetçiliğin Millet Tasarımı [Imagination of Nation by Islamic-Conservative Nationalism]'. Praksis 26 (2): 31-54.

Seawright, Jason, and John Gerring. 2008. 'Case Selection Techniques in Case Study Research'. Political Research Quarterly 61 (2): 294-308.

Sezgin, Yuksel. 2017. 'How a Constitutional Amendment Could End Turkey's Republic'. Washington Post. https://www.washingtonpost.com.

Somer, Murat. 2015. 'Whither with Secularism or Just Undemocratic Laiklik? In the Uncertain Path of the 'New Turkey', edited by Valeria Talbot, 23-48. Milano: ISPI.

Soner, Bayram Ali, and Şule Toktaş. 2011. 'Alevis and Alevism in the Changing Context'. Turkish Studies 12 (3): 419-34.

Spaskovska, Ljubica. 2014. 'From Feudal Socialism to Feudal Democracy'. OpenDemocracy, July 23. http://www.opendemocracy.net.

Stark, Rodney. 1999. 'Secularization, R.I.P.' Sociology of Religion 60 (3): 249-73.

Stavrakakis, Yannis. 2002. 'Religious Populism and Political Culture'. South European Society and Politics 7 (3): 29-52.

Subasi, Necdet. 2010. 'The Alevi Opening'. Insight Turkey 12 (2): 165-78.

Taggart, Paul. 2000. Populism. Buckingham: Open University Press.

Taleski, Dane. 2016. 'Escalation of Protests and Violence' Balkans in Europe Policy Blog. http://www.suedosteuropa.uni-graz.at/biepag.

Utrinski Vesnik. 2009. 'Incident at the Protest against a Church on the Square'. http://utrinski.mk/.

- 2011. 'The Gay Community Will Sue G.G. Stefan and Bishop Petar'.

Vecer. 2006. 'The Government Missed Kurban Bajram!?'

- 2007. 'VMRO-DPMNE Celebrates 17th Birthday'. http://vecer.mk.

. 2009. 'We Promised to Build a Church on the Square'.

VMRO-DPMNE. 2006. Doctrine: Values of VMRO-DPMNE. Skopje.

-2008. 'Rebirth in 100 Steps'. Skopje.

2014. 'Electoral Program of VMRO-DPMNE 2014 - 2018'. Skopje.

2015. 'Putting Foundation for Church "Christ Savior" in Karposh'. Skopje.

White, Jenny. 2014. Muslim Nationalism and the New Turks. Princeton: Princeton University Press.

Yabanci, Bilge. 2016a. 'Populism as the Problem Child of Democracy'. Southeast European and Black Sea Studies 16 (4): 591-617.

.2016b. Populism and Anti-establishment Politics in Kosovo. Contemporary Southeastern Europe 3(2): 17-43.

.2016c. Populism, elections and ever-present crisis. Independent Turkey. March, 20. 2016d. The Future of EU-Turkey Relations: Between Mutual Distrust and Interdependency", in FEUTURE Papers, No. 3, http://www.iai.it/en/node/6979

- 2017. 'Revolt on the Right: The Islamist "No" Campaign'. Independent Turkey. April 13. http://independentturkey.org/revolt-right-islamist-no-campaign/.

Yates, Joshua J. 2007. 'The Resurgence of Jihad Camp: The Spectre of Religious Populism'. SAIS Review 27 (1): 127-44.

24Vesti. 2013. 'Bishop Petar: He Who Does Not Care about Fertility Rates Is Not a Patriot'. 31 May. http://24vesti.mk/. 
Forthcoming in Religion, State and Society 
Figure 1: Populism and religion

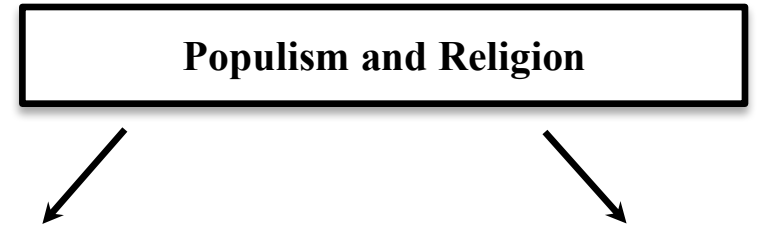

\begin{tabular}{|l|}
\hline Politicisation of religion: \\
Religious revolts and \\
social movements take on \\
people-centric populist \\
character.
\end{tabular}

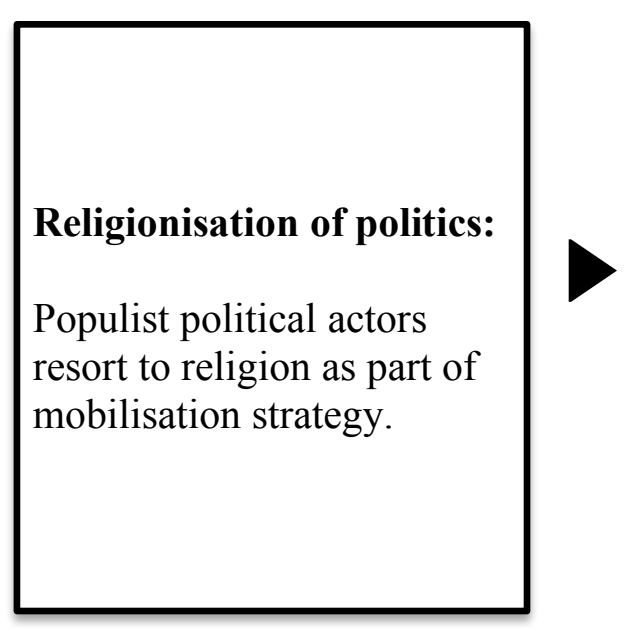

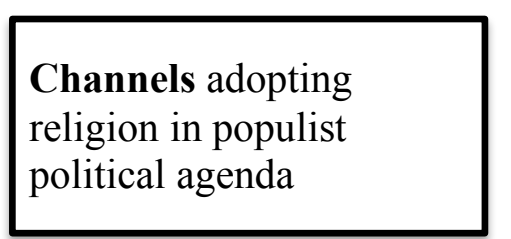

- Discursive: religious

references and symbols

in party documents and

speeches.

- Public policies:

majority religion

justifies policy choices

- Institutional alliances:

with nominally non-

partisan or political

religious actors/

authorities.
Objectives of populist

parties co-opting religion

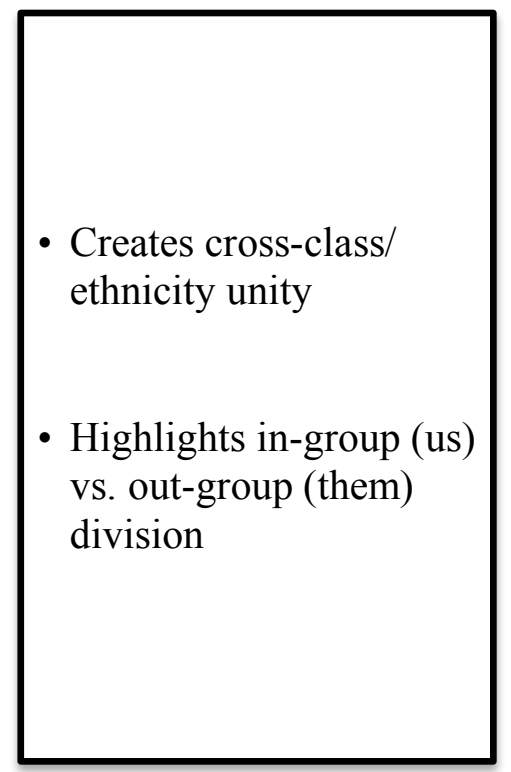


Forthcoming in Religion, State and Society

Figure 2: Timetable of general elections in Turkey and Macedonia

Sources: www.ysk.gov.tr and www.sec.mk.

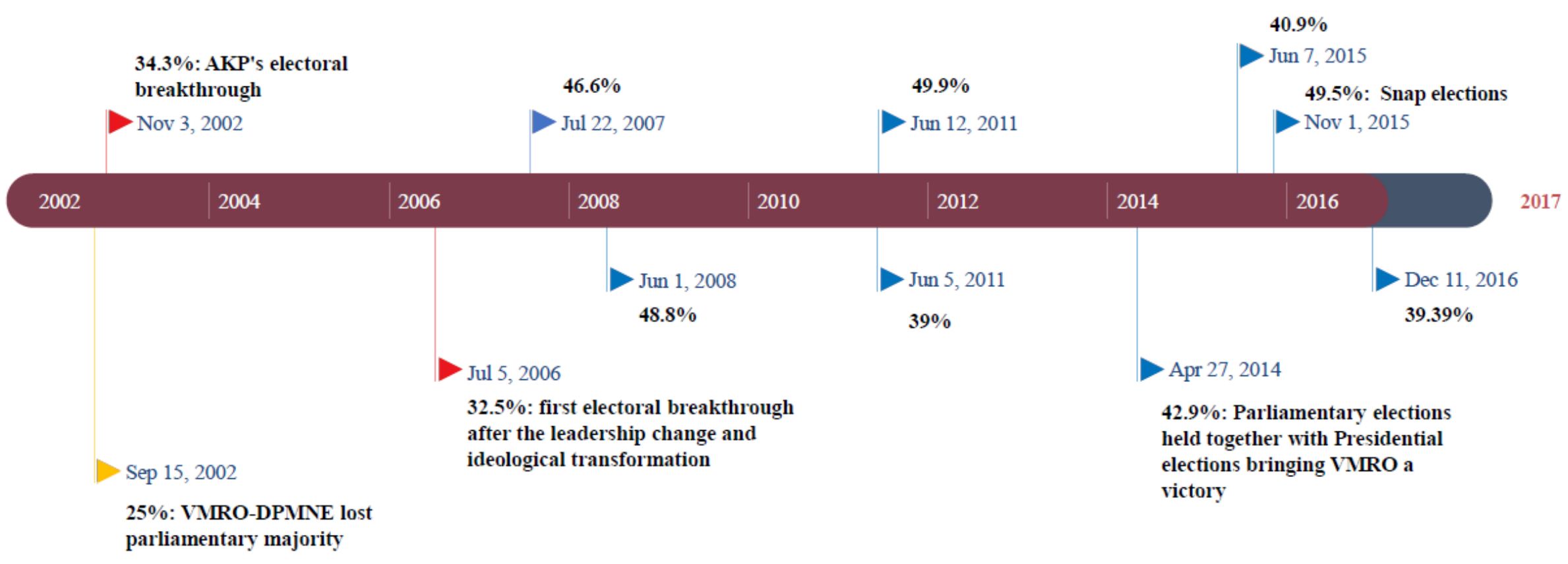


Forthcoming in Religion, State and Society

Table 1: Ruling populist parties in Europe

\begin{tabular}{|c|c|c|c|c|c|c|c|c|c|c|c|c|}
\hline & $\begin{array}{c}\text { AKP } \\
\text { Turkey }\end{array}$ & $\begin{array}{r}\text { VMRO- } \\
\text { DPMNE } \\
\text { Macedonia } \\
\end{array}$ & $\begin{array}{c}\text { PiS } \\
\text { Poland } \\
\end{array}$ & $\begin{array}{l}\text { FIDESZ } \\
\text { Hungary }\end{array}$ & $\begin{array}{c}\text { SNS } \\
\text { Serbia } \\
\end{array}$ & $\begin{array}{c}\begin{array}{c}\text { DPS } \\
\text { Montene- }\end{array} \\
\text { gro }\end{array}$ & $\begin{array}{c}\text { GERB } \\
\text { Bulgaria }\end{array}$ & $\begin{array}{c}\text { SYRIZA } \\
\text { Greece }\end{array}$ & $\begin{array}{c}\text { SVP } \\
\text { Switzer- } \\
\underline{\text { land }}\end{array}$ & $\begin{array}{c}\text { Progress } \\
\text { Party } \\
\text { Norway } \\
\end{array}$ & $\begin{array}{c}\text { Finns } \\
\text { Party } \\
\text { Finland } \\
\end{array}$ & $\begin{array}{c}\text { National } \\
\text { Alliance } \\
\text { Latvia }\end{array}$ \\
\hline 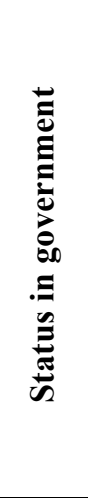 & $\begin{array}{l}\text { Single } \\
\text { ruling } \\
\text { party } \\
\text { since } \\
2002 .\end{array}$ & $\begin{array}{l}\text { Major party } \\
\text { in the rul- } \\
\text { ing coali- } \\
\text { tion since } \\
2006 \text {. }\end{array}$ & $\begin{array}{l}\text { Major } \\
\text { party in } \\
\text { the ruling } \\
\text { coalition } \\
(2005- \\
2007) \text {, } \\
\text { major } \\
\text { party in } \\
\text { ruling co- } \\
\text { alition } \\
\text { since } \\
2015 \text {. }\end{array}$ & $\begin{array}{l}\text { Major } \\
\text { party in } \\
\text { the ruling } \\
\text { coalition } \\
(1998- \\
2002) \text {, } \\
\text { major } \\
\text { party in } \\
\text { ruling co- } \\
\text { alition } \\
\text { since } \\
2010 .\end{array}$ & $\begin{array}{l}\text { Major } \\
\text { party in } \\
\text { the ruling } \\
\text { coalition } \\
\text { since } \\
2012 \text {. }\end{array}$ & $\begin{array}{l}\text { Major } \\
\text { party in } \\
\text { the ruling } \\
\text { coalition } \\
\text { since the } \\
\text { break-up } \\
\text { of Yugo- } \\
\text { slavia in } \\
1990 .\end{array}$ & $\begin{array}{l}\text { Single } \\
\text { ruling } \\
\text { party } \\
(2009- \\
2013) \text {, } \\
\text { major } \\
\text { party in } \\
\text { ruling co- } \\
\text { alition } \\
\text { since } \\
2014 \text {. }\end{array}$ & $\begin{array}{l}\text { Major } \\
\text { party in } \\
\text { the rul- } \\
\text { ing coa- } \\
\text { lition } \\
\text { since } \\
2015 \text {. }\end{array}$ & $\begin{array}{l}\text { Minority } \\
\text { party in } \\
\text { the broad } \\
\text { coalitions } \\
\text { at the } \\
\text { federal } \\
\text { level } \\
\text { since } \\
1950 \text { s. }\end{array}$ & $\begin{array}{l}\text { Minor } \\
\text { coalition } \\
\text { partner } \\
\text { since } \\
2013 \text {. }\end{array}$ & $\begin{array}{l}\text { Minor co- } \\
\text { alition } \\
\text { partner } \\
\text { since } 2015 \\
\text { after } 20 \\
\text { years in } \\
\text { opposi- } \\
\text { tion. }\end{array}$ & $\begin{array}{l}\text { Minor co- } \\
\text { alition } \\
\text { partner } \\
\text { since } \\
2011 .\end{array}$ \\
\hline 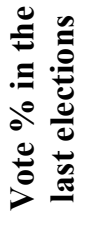 & $49.5 \%$ & $39.4 \%$ & $30 \%$ & $44.36 \%$ & $48.25 \%$ & $41.42 \%$ & $32.66 \%$ & $35.40 \%$ & $29.40 \%$ & $16.34 \%$ & $17.60 \%$ & $16.61 \%$ \\
\hline $\begin{array}{l}\text { b0 } \\
\frac{0}{8} \\
\frac{0}{0} \\
\frac{0}{0}\end{array}$ & $\begin{array}{l}\text { Right- } \\
\text { wing, } \\
\text { Con- } \\
\text { serva- } \\
\text { tive, } \\
\text { neo-lib- } \\
\text { eral }\end{array}$ & $\begin{array}{l}\text { Right-wing, } \\
\text { techno- } \\
\text { cratic, } \\
\text { Conserva- } \\
\text { tive, neo- } \\
\text { liberal }\end{array}$ & $\begin{array}{l}\text { Right- } \\
\text { wing, } \\
\text { Con- } \\
\text { servative }\end{array}$ & $\begin{array}{l}\text { Conserva- } \\
\text { tive, } \\
\text { Christian } \\
\text { Democ- } \\
\text { racy }\end{array}$ & $\begin{array}{l}\text { National- } \\
\text { ism, } \\
\text { right- } \\
\text { wing }\end{array}$ & $\begin{array}{l}\text { Centre- } \\
\text { left, tech- } \\
\text { nocratic }\end{array}$ & $\begin{array}{l}\text { Centre- } \\
\text { right, } \\
\text { conserva- } \\
\text { tive, } \\
\text { Christian } \\
\text { democ- } \\
\text { racy }\end{array}$ & $\begin{array}{l}\text { Far-left, } \\
\text { Left- } \\
\text { wing } \\
\text { popu- } \\
\text { lism, } \\
\text { demo- } \\
\text { cratic } \\
\text { social- } \\
\text { ism }\end{array}$ & $\begin{array}{l}\text { Since } \\
1990 \text { s, } \\
\text { radical- } \\
\text { ised to- } \\
\text { wards far } \\
\text { right, } \\
\text { anti-im- } \\
\text { migra- } \\
\text { tion. }\end{array}$ & $\begin{array}{l}\text { Right- } \\
\text { wing, } \\
\text { con- } \\
\text { servative } \\
\text { Euro- } \\
\text { sceptic, } \\
\text { national- } \\
\text { ist }\end{array}$ & $\begin{array}{l}\text { National- } \\
\text { ism, nativ- } \\
\text { ism, radi- } \\
\text { cal right, } \\
\text { anti-estab- } \\
\text { lishment }\end{array}$ & $\begin{array}{l}\text { National- } \\
\text { ism, na- } \\
\text { tivism, } \\
\text { conserva- } \\
\text { tism, eco- } \\
\text { nomic lib- } \\
\text { eralism }\end{array}$ \\
\hline
\end{tabular}


Forthcoming in Religion, State and Society

\begin{tabular}{|c|c|c|c|c|c|c|c|c|c|c|c|c|}
\hline 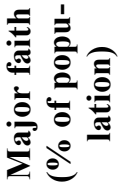 & $\begin{array}{l}\text { Sunni- } \\
\text { Islam }\end{array}$ & $\begin{array}{l}\text { Orthodox } \\
\text { Christian }\end{array}$ & Catholic & Catholic & $\begin{array}{l}\text { Orthodox } \\
\text { Christian }\end{array}$ & $\begin{array}{l}\text { Orthodox } \\
\text { Christian }\end{array}$ & $\begin{array}{l}\text { Orthodox } \\
\text { Christian }\end{array}$ & $\begin{array}{l}\text { Ortho- } \\
\text { dox } \\
\text { Chris- } \\
\text { tian }\end{array}$ & $\begin{array}{l}\text { Catholic, } \\
\text { Protestan } \\
\mathrm{t}\end{array}$ & $\begin{array}{l}\text { Lutheran } \\
\text { Christian }\end{array}$ & $\begin{array}{l}\text { Lutheran } \\
\text { Christian }\end{array}$ & $\begin{array}{l}\text { Lutheran } \\
\text { Christian, } \\
\text { Catholic }\end{array}$ \\
\hline 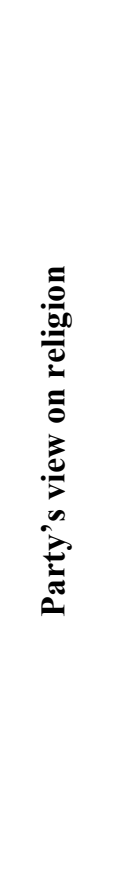 & $\begin{array}{l}\text { Empha- } \\
\text { sis on } \\
\text { Muslim } \\
\text { nation- } \\
\text { alism as } \\
\text { part of } \\
\text { national } \\
\text { identity. } \\
\text { In- } \\
\text { creased } \\
\text { role of } \\
\text { public } \\
\text { Islam } \\
\text { through } \\
\text { the state } \\
\text { con- } \\
\text { trolled } \\
\text { reli- } \\
\text { gious } \\
\text { author- } \\
\text { ity 'Di- } \\
\text { yanet'. }\end{array}$ & $\begin{array}{l}\text { Religious } \\
\text { norms and } \\
\text { ideas con- } \\
\text { sidered a } \\
\text { part of na- } \\
\text { tional iden- } \\
\text { tity. Close } \\
\text { ties and } \\
\text { mutual ac- } \\
\text { commoda- } \\
\text { tion with } \\
\text { Macedo- } \\
\text { nian Ortho- } \\
\text { dox } \\
\text { Church. }\end{array}$ & $\begin{array}{l}\text { Catholic } \\
\text { morals } \\
\text { and val- } \\
\text { ues in } \\
\text { party pro- } \\
\text { gramme. } \\
\text { Discourse } \\
\text { to desig- } \\
\text { nate "pi- } \\
\text { ous and } \\
\text { virtuous } \\
\text { "real } \\
\text { Poles",, }\end{array}$ & $\begin{array}{l}\text { Emphasis } \\
\text { on Chris- } \\
\text { tian cul- } \\
\text { ture as } \\
\text { part of na- } \\
\text { tional tra- } \\
\text { dition and } \\
\text { values. Is- } \\
\text { lamopho- } \\
\text { bia. }\end{array}$ & $\begin{array}{l}\text { Religion } \\
\text { forms a } \\
\text { part of } \\
\text { policy to- } \\
\text { wards } \\
\text { Serbs in } \\
\text { the neigh- } \\
\text { bouring } \\
\text { countries. } \\
\text { Albeit } \\
\text { close ties } \\
\text { with the } \\
\text { Church, } \\
\text { the lead- } \\
\text { ership } \\
\text { empha- } \\
\text { sises sec- } \\
\text { ular state. }\end{array}$ & $\begin{array}{l}\text { Support } \\
\text { for resto- } \\
\text { ration of } \\
\text { Montene- } \\
\text { grin Or- } \\
\text { thodox } \\
\text { Church, } \\
\text { which is } \\
\text { consid- } \\
\text { ered key } \\
\text { to differ- } \\
\text { entiate } \\
\text { Montene- } \\
\text { grin iden- } \\
\text { tity from } \\
\text { Serbian. }\end{array}$ & $\begin{array}{l}\text { Party } \\
\text { leader } \\
\text { Borissov } \\
\text { identifies } \\
\text { with the } \\
\text { church. } \\
\text { Religion } \\
\text { is used to } \\
\text { define } \\
\text { and 'oth- } \\
\text { erise' } \\
\text { Muslim } \\
\text { Bulgarian } \\
\text { Turks. }\end{array}$ & $\begin{array}{l}\text { Secular } \\
\text { and left- } \\
\text { ist ideol- } \\
\text { ogy of } \\
\text { SYRIZA } \\
\text { often } \\
\text { gets the } \\
\text { party in } \\
\text { direct } \\
\text { conflict } \\
\text { with the } \\
\text { Greek } \\
\text { Ortho- } \\
\text { dox } \\
\text { Church }\end{array}$ & $\begin{array}{l}\text { Emphasis } \\
\text { on Chris- } \\
\text { tian iden- } \\
\text { tity to de- } \\
\text { fine the } \\
\text { 'true na- } \\
\text { tion' } \\
\text { against } \\
\text { Muslim } \\
\text { immi- } \\
\text { grants. }\end{array}$ & $\begin{array}{l}\text { Christi- } \\
\text { anity em- } \\
\text { phasised } \\
\text { as part of } \\
\text { national } \\
\text { culture } \\
\text { and iden- } \\
\text { tity. }\end{array}$ & $\begin{array}{l}\text { Party pro- } \\
\text { motes an } \\
\text { anti-Mus- } \\
\text { lim/Islam } \\
\text { stance, } \\
\text { Christian } \\
\text { values of- } \\
\text { ten em- } \\
\text { phasised } \\
\text { to advo- } \\
\text { cate } \\
\text { 'Finnish- } \\
\text { ness'. }\end{array}$ & $\begin{array}{l}\text { Religion } \\
\text { is not part } \\
\text { of party } \\
\text { pro- } \\
\text { gramme. } \\
\text { Campaign } \\
\text { for sus- } \\
\text { pending } \\
\text { Muslim } \\
\text { refugees. }\end{array}$ \\
\hline 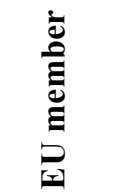 & No & No & Yes & Yes & No & No & Yes & Yes & No & No & Yes & Yes \\
\hline
\end{tabular}

